\title{
\begin{tabular}{l|l} 
신종 인플루엔자 $\mathrm{A}(\mathrm{H} 1 \mathrm{~N} 1)$ 의 진단과 치료 & Review
\end{tabular}
}

\author{
위성헌, 김우주1,"
}

가톨릭대학교 의과대학 내과학교실, ${ }^{1}$ 고려대학교 의과대학 내과학교실

\section{Diagnosis and Management of Novel Influenza A (H1N1)}

Seong Heon Wie, Woo Joo Kim ${ }^{1, *}$

Department of Internal Medicine, The Catholic University of Korea College of Medicine, ${ }^{1}$ Korea University College of Medicine, Seoul, Korea

Since the World Health Organization has officially declared a global influenza pandemic, the number of human cases of pandemic influenza A (H1N1) in 2009 has been increasing in many countries. Especially from mid-October, the number of domestic cases of influenza A (H1N1) has been exponentially increasing, with the number of confirmed cases reaching over 100,000. The clinical symptoms of novel influenza A (H1N1) include fever, cough, sore throat, runny nose, myalgia, headache, chills and fatigue. Nucleic acid amplification tests, including real time RT-PCR assay specific for 2009 novel influenza A (H1N1) can be used in the patients with suspected influenza. Antiviral treatment by using neuraminidase inhibitors (oseltamivir, zanamivir) is recommended by Centers for Disease Control and Prevention for treatment of novel influenza A (H1N1) disease. Personal and public efforts to control the outbreak of novel influenza A (H1N1) disease are required. Vaccination against pandemic $\mathrm{H} 1 \mathrm{~N} 1$ is important for personal health, but also to build community-level immunity to novel influenza A.

Keywords: Novel Influenza A (H1N1); Oseltamivir; Zanamivir

\section{서론}

2009년 4월 17일 미국 캘리포니아에서 신종 인플루엔자 A 형 (H1N1) 바이러스에 감염된 소아가 발견되고, 4월 24일 미 국 정부가 돼지에서 유래된 신종 인플루엔자가 시작되었음을 공표하였으며 동시에 멕시코에서 854 명의 의심환자와 59명 의 사망자를 발표해 전 세계를 공포에 떨게 하였다. 4 월 25 일 세계보건기구 $(\mathrm{WHO})$ 는 긴급회의 후 신종 인플루엔자에 의한 대유행 가능성을 경고하면서 '국제적인 공중 보건 위기 상황'

Received: November 2, 2009, Accepted: November 5, 2009

${ }^{*}$ Corresponding Author: Woo Joo Kim

Tel: 02-2626-3051, Fax: 02-2626-1105

E-mail: wjkim@korea.ac.kr

Korean Journal of Family Medicine

Copyrights $\odot 2009$ by The Korean Academy of Family Medicine
을 선포하였고 4월 27일과 29일에 평소 유지해오던 대유행 경 보 수준 3 단계를 각각 4단계와 5단계로 급박하게 격상시켰다. 초기에 멕시코와 미국 등 북미 지역에서만 국한되어 유행하 던 신종 인플루엔자가 유럽, 아시아 및 오세아니아 대륙에 전 파되면서 $\mathrm{WHO}$ 는 6월 11 일에 금세기 최초의 인플루엔자 대 유행을 선언하였다. ${ }^{1-3)}$

2009년 10월 11일까지 WHO는 전 세계적으로 399,232명 이 신종 인플루엔자로 확진되었고 4,735명 이상의 사망자가 발생한 것으로 보고하였다. 물론 많은 국가들에서 환자수의 집계를 중단한 상태이므로 발생 환자수와 사망자는 이보다 더 많을 것으로 추정하고 있다. 2009년 10월 WHO 보고에 따 르면 북반구 온대 기후지역에 있는 많은 나라에서 인플루엔 자 증상을 보이는 비율이 이전의 가을이나 초겨울에 증가하 는 비율보다 더 많이 증가하고 있다. 국내에서도 8 월 중순에서 10 월 중순까지 인플루엔자 유사환자 분율이 유행 주의보 기 준을 훨씬 초과하고 있으며, 10 월 중순 이후는 신종 인플루엔 자 확진 환자가 학생들을 중심으로 급격하게 증가하고 있다. 
현재까지 분석된 대유행 신종 H1N1 인플루엔자 바이 러스는 항원형이나 유전학적으로 A/California/7/2009-like pandemic H1N1 2009 virus와 유사한 것으로 보고되어 있다. 미 국 질병관리본부(Centers for Disease Control and Prevention)는 신종 인플루엔자 A (H1N1) 바이러스를 북미의 돼지, 사람 및 조류 인플루엔자 바이러스와 유라시안 돼지 인플루엔자 바이 러스의 유전자들이 혼합된 4종 재편성 바이러스로 보고하였 다. 금번 신종 인플루엔자 바이러스는 인류가 경험하지 못한 바이러스이면서 사람 간에 효과적인 감염전파 능력을 가지고 있으며 일부에서는 사망을 초래하고 있다. 그러므로 신종 인 플루엔자의 신속한 진단, 치료 및 예방을 위한 노력이 매우 중 요하다.

\section{진단}

\section{1. 임상 소견}

신종 인플루엔자의 잠복기, 감염경로 및 초기 임상 증상 등은 계절인플루엔자와 별 차이가 없는 것으로 알려지고 있 다. 신종 인플루엔자의 잠복기는 계절 인플루엔자와 비슷한 1-7일로 알려져 있고, 대부분 감염자와 접촉 후 1-4일 이내에 발병한다.

임상 증상은 계절 인플루엔자와 마찬가지로 발열 $(90 \%$ 이 상), 기침(90\% 내외), 인후통(60-70\%), 콧물, 두통 및 근육통 (60\% 내외) 등이 나타나며, 설사와 구토 등 위장관 증상이 환 자의 $10-25 \%$ 에서 발생한다.

신종 인플루엔자는 열이 없는 경증의 상부 호흡기 감염증 에서, 원발성 바이러스성 폐렴, 이차성 세균성 폐렴 및 생명을 위협할수 있는 중증의 폐렴 등 다양한 임상 양상을 보일 수 있 다. 대부분의 경우는 경증으로 나타나 항바이러스제 투약 없 이도 7일 이내에 자연 치유되지만 2-5\% 정도는 입원을 요하 는 것으로 알려져 있다. ${ }^{4,5)}$

호흡부전을 보이는 폐렴이나 다발성장기부전의 소견을 보이는 경우에 입원이 필요하며, 증상 시작 후 3 일 이상 고열 이 지속되거나 호흡 곤란, 객혈, 흥통 등이 동반되는 경우들이 중증을 시사할 수 있는 임상 소견들이다. 입원 환자의 검사실 소견으로는 혈중 $\mathrm{LDH}$ 증가, 신부전, 림프구 감소증, 백혈구 감 소증 또는 백혈구 증가증, $\mathrm{CPK}$ 증가 등이 있고 흥부 X-선 소견 으로는 양측성, 다발성 침윤이 대표적인 소견이다.

입원 또는 사망자에 관한 논문 등을 분석하였을 때, 65 세 이상 성인, 만성 폐질환, 심혈관질환, 당뇨병, 만성 신질환, 만 성 간질환, 면역결핍질환, 5 세 미만 소아, 임신부 등이 합병증
Table 1. Groups at high risk for complications of novel influenza A (H1N1).

\begin{tabular}{l}
\hline Adults $\geq 65$ y of age \\
Children $<5$ y (especially children younger than 2 y old) \\
Pregnant women \\
People who have chronic medical conditions \\
Blood disorder (including sickle cell disease) \\
Cancer \\
Chronic liver disease \\
Chronic lung disease (including asthma or chronic obstructive \\
pulmonary disease) \\
Chronic metabolic disorder (including diabetes mellitus) \\
Chronic renal disease \\
Heart disease (excluding hypertension) \\
Immunosuppressed state (HIV, transplantation, \\
immunosuppressive therapy) \\
Neurological disorders (epilepsy, cerebral palsy, brain or \\
spinal cord injuries) \\
Neuromuscular disorders (muscular dystrophy and \\
multiple sclerosis)
\end{tabular}

발생의 가능성이 높은 고위험군으로 분류되고 있다(Table 1).-8)

\section{2. 실험실적 진단}

발열 및 기침, 인후통 등 호흡기 증상만으로는 신종 인플 루엔자와 계절 인플루엔자의 감별이 어려우므로 신종 인플루 엔자 감염이 의심되는 경우는 실험실적 진단을 실시해야 확 진할 수 있다. 임상적인 증상이 경미한 경우에는 반드시 실험 실적 검사가 필요하지는 않지만, 신종 인플루엔자 의증으로 입원하는 환자, 치료나 감염 관리 및 접촉자 관리를 위하여 확 진이 필요한 경우, 신종 인플루엔자 감염이 의심되는 급성 질 환으로 사망한 환자의 경우는 실험실적 검사가 필요하다. ${ }^{8,9)}$ 그러나 실험실적 확진 검사 실시의 필요성은 신종 인플루엔 자의 지역사회 유행 상황에 따라 달라질 수 있는데, 유행초기 에는 모든 의심 환자나 추정 환자를 대상으로 확진 검사를 시 행하지만, 지역사회에서 지속적으로 발생하고 환자수가 증가 하는 경우에는 의료 자원의 효율적 이용을 위하여 고위험군 환자나 입원한 중증 환자들에 대해서만 주로 시행할 수도 있 다. 급성 열성호흡기 질환자에서 real-time reverse transcriptasepolymerase chain reaction (RT-PCR), conventional RT-PCR, 바이 러스 배양 등을 통해 신종 인플루엔자 A $(\mathrm{H} 1 \mathrm{~N} 1)$ 바이러스 감 
염이 확인되면 신종 인플루엔자 A (H1N1)으로 확진할 수 있 다. 바이러스 배양을 통해서도 확진이 가능하지만 적어도 2-3 일의 시간이 소요되기 때문에 신속한 진단을 위해서는 주로 real-time RT-PCR이 확진검사법으로 이용되고 있다.

확진 검사를 실시하기 위해서는 구강인두, 비인두, 비강 등에서 채취된 상부호흡기검체가 필요하다. 증상이 발생한 후 빠른 시간 내에 도말이나 흡인을 통해 검체를 채취해야한 다. 기관폐포세척술(BAL)이나 객담도 검체로 이용될 수 있고 기관 삽관된 상태에서는 기관흡인으로 채취될 수 있다. 채취 된 검체는 무균 상태의 수송배지에 넣어 $4^{\circ} \mathrm{C}$ 로 유지하여 가급 적 24시간 이내에 검사실로 보낸다.,10)

인플루엔자 바이러스에 대한 신속항원검사는 30 분 이내 에 결과를 확인할 수 있어 계절인플루엔자의 진단에 유용하 게 사용되고 있다. 그러나 신종인플루엔자에 대한 신속항원 검사의 민감도는 9.6-51\%로 계절인플루엔자의 70-80\%에 비 해 낮게 보고되고 있어 확진검사로 사용될 수 없다. ${ }^{11,12)}$

\section{치료}

\section{1. 항바이러스제 치료}

인플루엔자 치료에 효과적인 항바이러스제로는 neuraminidase 억제제인 oseltamivir와 zanamivir, M2 단백질을 억제 하는 amantadine과 rimantadine 등이 있다. 신종 인플루엔자 바 이러스는 amantadine과 rimantadine에 대해서 내성을 보여, 효 과적인 항바이러스제로는 oseltamivir와 zanamivir가 권장되 고 있다. 2008년과 2009년의 계절 인플루엔자 A (H1N1) 바이 러스가 oseltamivir에 대해 내성을 보이는 경우가 많았지만, 대 유행 신종 인플루엔자 A (H1N1)의 경우는 oseltamivir에 감수 성을 보이고 있다. 그러나 2009년 8월에 신종 인플루엔자 A (H1N1)에서 oseltamivir 내성 바이러스주가 보고되었고, 2009 년 가을과 겨울에 유행할 계절 인플루엔자와의 재편성에 따라 oseltamivir 내성의 획득 가능성을 배제할 수 없는 상황이다. ${ }^{13,14)}$ 특히, 바이러스 증식 기간이 길고 바이러스 배출량이 많은 면 역저하환자나 소아의 경우는 내성이 더 쉽게 유도될 수 있다.

신종 인플루엔자 환자에 대한 neuraminidase 억제제의 투 여 효과를 연구한 객관적인 연구 결과는 아직까지 보고되 지 않았다. 따라서 계절 인플루엔자에 대한 neuraminidase 억 제제의 치료 효과를 신종 인플루엔자 환자에게 적용하고 있 다. 인플루엔자의 임상 증상이 시작되고 36-48시간 이내에 oseltamivir를 투여하면 증상 기간을 1-2일 단축시키고, 세균 성 폐렴 등 하부 호흡기 감염을 감소시키는 것으로 보고되어
있다. 계절 인플루엔자에 대한 oseltamivir의 임상 효과에 관한 연구 결과를 바탕으로 할 때, 신종 인플루엔자에서도 증상 시 작 2일 이내에 oseltamivir 등의 neuraminidase 억제제를 투여하 면 이환기간을 단축시키고, 폐렴 등 합병증 발생이 감소할 것 으로 예상하고 있다. 또한 일부 연구에서는 인플루엔자의 임 상 증상이 시작되고 48시간 이후에 내원한 중증 환자에서도 항바이러스제 투여가 효과있다고 보고하고 있어 증상 시작 2 일 이후의 중증 인플루엔자나 폐렴 환자에 대해서도 항바이 러스제가 투여될 수 있다. ${ }^{79}$

신종 인플루엔자 의심 환자나 확진 환자에는 neuraminidase 억제제가 투여될 수 있지만, 모든 신종 인플루엔자 환자 에서 항바이러스제 치료가 필요한 것은 아니다. 지역사회에 서 신종 인플루엔자 환자가 급격히 증가하는 경우는 역학적 특성, 공중보건대책의 목표, 및 국가의 항바이러스제 비축량 에 따라 환자 발생 상황에 대응할 수 있는 적절한 치료 기준을 적용해야 한다. 일반적으로는 경증 환자에 대해서는 투약 없 이 7일간의 자택 격리가 권장되고 고위험군에 한하여 항바이 러스제가 투여될 수도 있지만, 발생 상황에 따라서는 인플루

Table 2. Neuraminidase inhibitors for the treatment and prevention of influenza.

\begin{tabular}{|c|c|c|}
\hline Agent, group & Treatment (5 days) & Prevention (10 days) \\
\hline \multicolumn{3}{|c|}{ Oseltamivir (Tamiflu) } \\
\hline Adults & $\begin{array}{l}75 \text { mg capsule } \\
\text { twice daily }\end{array}$ & $\begin{array}{l}75 \text { mg capsule } \\
\text { once daily }\end{array}$ \\
\hline \multicolumn{3}{|c|}{ Children ( $\geq 12$ mo) } \\
\hline $15 \mathrm{~kg}$ or less & $30 \mathrm{mg}$ twice daily & $30 \mathrm{mg}$ once per $\mathrm{d}$ \\
\hline $15-23 \mathrm{~kg}$ & $45 \mathrm{mg}$ twice daily & $45 \mathrm{mg}$ once per $\mathrm{d}$ \\
\hline $24-40 \mathrm{~kg}$ & $60 \mathrm{mg}$ twice daily & $60 \mathrm{mg}$ once per $\mathrm{d}$ \\
\hline$>40 \mathrm{~kg}$ & 75 mg twice daily & $75 \mathrm{mg}$ once per d \\
\hline \multicolumn{3}{|l|}{ Infants $(<12 \mathrm{mo})$} \\
\hline$<3 \mathrm{mo}$ & $12 \mathrm{mg}$ twice daily & * \\
\hline $3-5 \mathrm{mo}$ & 20 mg twice daily & $20 \mathrm{mg}$ once per $\mathrm{d}$ \\
\hline $6-11 \mathrm{mo}$ & $25 \mathrm{mg}$ twice daily & $25 \mathrm{mg}$ once per $\mathrm{d}$ \\
\hline \multicolumn{3}{|c|}{ Zanamivir (Relenza) } \\
\hline Adults & $\begin{array}{l}10 \text { mg inhalations } \\
\text { twice daily }\end{array}$ & $\begin{array}{l}10 \mathrm{mg} \text { inhalations } \\
\text { once daily }\end{array}$ \\
\hline Childrens & $\begin{array}{l}10 \text { mg inhalations } \\
\text { twice daily } \\
\text { ( } \geq 7 \text { y or older) }\end{array}$ & $\begin{array}{l}10 \text { mg inhalations } \\
\text { once daily } \\
\text { ( } \geq 5 \text { y or older) }\end{array}$ \\
\hline
\end{tabular}

${ }^{*}$ Not recommended unless situation judged critical. 
엔자 의심 환자들에게 확진 검사 없이 경험적으로 항바이러 스제의 투여가 권장될 수도 있는데, 공중보건대책의 목표에 따라 발생 상황이나 의료 자원 등을 참고하여 신중하게 결정 되어야 할 것이다. ${ }^{9)}$ 국내의 경우도 4 월 말 멕시코를 여행하고 귀국한 51세 여자가 신종 인플루엔자 A (H1N1) 감염으로 확 진되었다. 8 월 15 일 첫 사망자가 발생한 이후 고위험군, 중증 환자 위주로 항바이러스제 투여 정책을 유지하였으나, 10 월 말 이후 사망 환자들이 속출하고 감염자들이 폭발적으로 발 생하면서 항바이러스제를 적극적으로 투여하도록 투여 기준 이 일부 완화되었다.

신종 인플루엔자에 사용될 수 있는 항바이러스제로 oseltamivir는 경구로 복용하고, zanamivir는 별도의 기구를 이용 하여 흡인하는데 용법과 용량은 Table 2 와 같다. 1 세 미만에 서 oseltamivir의 치료 및 예방목적 투여는 신종 인플루엔자 의 유행발생에 의해 한시적으로 승인되어 시행되고 있다. Oseltamivir는 복용자의 2-10\%에서 일시적인 오심, 구토, 복통 및 설사 등의 위장관 부작용이 있을 수 있는데, 이는 음식과 함 께 복용하면서 감소될 수 있다. Oseltamivir는 신장으로 배설되 므로 사구체여과율이 $30 \mathrm{~mL} / \mathrm{minutes}$ 미만인 신기능저하 환자 에서는 감량하여 투여하거나 zanamivir의 투여가 권고되고 있 다. Zanamivir는 신부전 환자에서 감량할 필요는 없지만, 5 세 이하 소아 또는 노인에서는 흡입 기구 사용이 익숙하지 않아 투약이 어려울 수 있다. 또한 천식 등 기관지 과민성이 있는 환 자에서는 흡입용 zanamivir가 기관지 수축을 초래할 수 있으므 로 속효성 기관지확장제를 준비하고 zanamivir를 투여해야 한 다. ${ }^{799}$

\section{2. 임신부에서 치료}

임신부는 계절인플루엔자 감염 후에 합병증의 발생 가 능성이 높다고 알려져 있는데, 신종 인플루엔자에도 취약하 고 감염 시 사망 사례가 보고되고 있어 고위험군으로 분류 되고 있다. 감염된 임신부의 증상은 일반적인 신종 인플루 엔자 증상과 큰 차이가 없고 대부분 경미한 경과를 보이지 만, 일차성 바이러스성 폐렴이나 이차성 세균성 폐렴들과 같 은 합병증의 발생 가능성이 높아 조기 진단과 치료가 요구된 다. Neuraminidase 억제제는 "임신 C군" 약제로 분류되고 있 고 안정성이 정확하게 확인된 바 없지만, 임신 중 oseltamivir나 zanamivir를 복용한 여성이나 태어난 영아에서 아직까지 이상 반응은 보고되지 않았다. 임신이 oseltamivir나 zanamivir 투여 의 금기증은 아니며, 임신부나 태아에 대한 이상 반응이 알려 져 있지 않으므로 신종 인플루엔자가 의심되거나 확진된 임 신부에서는 투여의 이점과 위험성을 비교하여 신중하게 투여
할수 있다. ${ }^{915)}$

\section{3. 화학적 예방}

신종 인플루엔자 확진 또는 추정 환자의 가정 내 밀접한 접촉자, 적절한 개인 보호 장구를 착용하지 않은 상태에서 접촉한 의료인 혹은 방역요원에 대해서는 화학적 예방요법 이 추천된다. 화학적 예방요법에 사용될 수 있는 항바이러스 제로 oseltamivir나 zanamivir가 사용될 수 있고 용법과 용량은 Table 2 와 같다. 노출 후 화학적 예방요법은 신종 인플루엔자 감염이 확진되거나 의심되는 사람과 밀접하게 접촉한 상황을 근거로 마지막 접촉 이후 10 일 동안 시행되어야 한다. 신종 인 플루엔자 확진 환자는 대개 증상 발생 1 일 전부터 증상 발생 7 일까지 감염력이 있다고 알려져 있으므로 이 기간 중에 개인 보호 장구 없이 밀접하게 접촉한 의료인의 경우에 화학적 예 방요법이 필요하다. 감염력이 없는 기간에 노출되었거나 집 단(학교, 직장)내에서 바이러스에 노출될 가능성이 있는 건 강한 성인이나 아이들에게 반드시 예방적 화학요법이 필요한 것은 아니다. ${ }^{79)}$

\section{4. 예방 접종}

신종 인플루엔자의 예방을 위한 가장 좋은 해결책은 백신 의 개발 및 투여이다. 미국, 일본, 유럽 등의 선진국에서 신종 인플루엔자 백신을 개발하여 투여중이다. 국내의 회사에서도 신종 인플루엔자 백신을 개발하여 임상 시험을 시행하였다. 10 월말부터 국내에서도 의료인을 시작으로 백신접종이 진행 되고 있고, 초, 중, 고교 학생과 고위험군, 일반인 등에 대한 예 방 접종이 성공적으로 진행되어 신종 인플루엔자의 광범위한 유행이차단될 것을 기대하고 있다.

\section{결론}

2009년 6월 11일에 WHO는 금세기 최초의 인플루엔자 대 유행을 선언하였고 국내에서도 10 월 중순 이후로 신종 인플 루엔자 확진 환자가 급격하게 증가하고 있다. 신종인플루엔 자의 임상 증상 등은 계절인플루엔자와 큰 차이가 없는 것으 로 알려지고 있으며 신속한 진단을 위해서 real-time RT-PCR 방 법이 널리 이용되고 있다.

신종 인플루엔자 바이러스에 효과적인 항바이러스제로 는 oseltamivir와 zanamivir가 권장되고 있으며, 치료 및 화학적 예방요법에 이용되고 있다. 신종 인플루엔자의 예방을 위해 서는 손씻기와 마스크 착용, 기침 예절 준수 등을 철저히 시행 
해야한다. 신종 인플루엔자의 확산을 차단하기 위한 가장 좋 은 해결책은 예방 백신의 개발 및 투여이다.

\section{요약}

멕시코와 미국 등 북미 지역에서 시작된 신종 인플루엔자가 전 세계로 전파되면서 $\mathrm{WHO}$ 는 6 월 11 일에 금세기 최초의 인 플루엔자 대유행을 선언하였고, 국내에서도 10 월 중순 이후 는 신종 인플루엔자 확진 환자가 학생들을 중심으로 급격하 게 증가하여 약 100,000 명 이상의 확진 환자가 보고되어 있다. 신종인플루엔자의 임상 증상은 계절인플루엔자와 별 차이가 없는 것으로 알려지고 있는데, 발열, 기침, 인후통, 콧물, 두통 및 근육통 등이 나타나며, 설사와 구토 등 위장관 증상이 나타 나기도 한다. 잠복기는 계절 인플루엔자와 비슷한 1-7일로 알 려져 있고, 대부분 감염자와 접촉 후 1-4일 이내에 발병한다. 급성 열성호흡기질환 환자에서 real-time RT-PCR, conventional RT-PCR, 바이러스 배양 등을 통해 신종 인플루엔자 A (H1N1) 바이러스 병원체 감염이 확인되면 신종 인플루엔자 A (HIN1) 으로 확진할 수 있다. 신속한 진단을 위해 주로 real-time RT$\mathrm{PCR}$ 이 확진검사법으로 이용되고 있다. 신종 인플루엔자 바이 러스에 효과적인 항바이러스제로는 oseltamivir와 zanamivir가 권장되고 있다. 신종 인플루엔자로 진단된 성인 환자의 치료 를 위해서는 oseltamivir $75 \mathrm{mg}$ 캡슐을 1 일 2 회, 5 일간 투여할 수 있다. 노출 후 화학적 예방을 위해서는 oseltamivir $75 \mathrm{mg}$ 캡슐 을 1 일 1 회로, 10 일간 투여한다. 신종 인플루엔자의 예방을 위 한 가장 좋은 해결책은 백신의 개발 및 투여이다.

중심단어: 신종 인플루엔자; Oseltamivir; Zanamivir

\section{REFERENCES}

1. Fraser C, Donnelly CA, Cauchemez S, Hanage WP, Van Kerk ᄒ hove MD, Hollingsworth TD, et al. Pandemic potential of a strain of influenza A (H1N1): early findings. Science 2009;324:1557-61.

2. Turbelin C, Pelat C, Boelle PY, Levy-Bruhl D, Carrat F, Blanchon T, et al. Early estimates of 2009 pandemic influenza A (H1N1) virus activity in general practice in France: incidence of influenza-like illness and age distribution of reported cases. Euro
Surveill 2009; 14:19341.

3. Garske T, Legrand J, Donnelly CA, Ward H, Cauchemez S, Fraser C, et al. Assessing the severity of the novel influenza A/ H1N1 pandemic. BMJ 2009;339:b2840.

4. World Health Organization. Human infection with new influenza A (H1N1) virus: clinical observations from Mexico and other affected countries, May 2009. Wkly Epidemiol Rec 2009;84:185-9.

5. Kaufman MA, Duke GJ, McGain F, French C, Aboltins C, Lane $\mathrm{G}$, et al. Life-threatening respiratory failure from $\mathrm{H} 1 \mathrm{~N} 1$ influenza 09 (human swine influenza). Med J Aust 2009;191:214-6.

6. Vaillant L, La Ruche G, Tarantola A, Barboza P. Epidemiology of fatal cases associated with pandemic H1N1 influenza 2009. Euro Surveill 2009;14:19309.

7. Zimmer SM, Burke DS. Historical perspective: emergence of influenza A (H1N1) viruses. N Engl J Med 2009;361:279-86.

8. Rothberg MB, Haessler SD, Brown RB. Complications of viral influenza. Am J Med 2008;121:258-64.

9. Kim WJ. Epidemiology, clinical manifestations, and management of pandemic novel influenza A (H1N1). Korean J Med 2009;77:157-64.

10. Carr MJ, Gunson R, Maclean A, Coughlan S, Fitzgerald M, Scully M, et al. Development of a real-time RT-PCR for the detection of swine-lineage influenza A (H1N1) virus infections. J Clin Virol 2009;45:196-9.

11. Ginocchio CC, Zhang F, Manji R, Arora S, Bornfreund M, Falk $\mathrm{L}$, et al. Evaluation of multiple test methods for the detection of the novel 2009 influenza A (H1N1) during the New York City outbreak. J Clin Virol 2009;45:191-5.

12. Faix DJ, Sherman SS, Waterman SH. Rapid-test sensitivity for novel swine-origin influenza A (H1N1) virus in humans. N Engl J Med 2009;361:728-9.

13. Scalera NM, Mossad SB. The first pandemic of the 21st century: a review of the 2009 pandemic variant influenza A (H1N1) virus. Postgrad Med 2009;121:43-7.

14. Centers for Disease Control and Prevention (CDC). Oseltamivir-resistant novel influenza A (H1N1) virus infection in two immunosuppressed patients-Seattle, Washington, 2009. MMWR Morb Mortal Wkly Rep 2009;58:893-6.

15. Mangtani P, Mak TK, Pfeifer D. Pandemic H1N1 infection in pregnant women in the USA. Lancet 2009;374:429-30. 